\title{
Some Individual Difficulties in the Study of Music
}

\section{Esther Allen Gaw PH. D.}

To cite this article: Esther Allen Gaw PH. D. (1922) Some Individual Difficulties in the Study of Music, The Journal of Educational Research, 5:5, 381-388, DOI: 10.1080/00220671.1922.10879266

To link to this article: http://dx.doi.org/10.1080/00220671.1922.10879266

曲 Published online: 15 Dec 2014.

Submit your article to this journal $\widetilde{ }$

View related articles ๔

Citing articles: 1 View citing articles $₫$ 


\title{
SOME INDIVIDUAL DIFFICULTIES IN THE STUDY OF MUSIC
}

\author{
Esther Allen Gaw, Ph.D. \\ San Francisco State Normal School
}

One of the requirements of the Board of Education in California is that every teacher shall be able to teach the music of the grade to which she is assigned. She must, therefore, be able to sing the songs of the "Progressive Series," which is the prescribed textbook, and to read at sight readily enough to teach any other songs that may be needed. She must understand the technique of our music system, that is, the keys and their relationships and the staff notation.

In order to teach the staff, the keys, and the relationships of the syllables, the music department of the San Francisco State Normal School uses a series of bulletins which outline the minimum requirements. These are arranged in three units upon each one of which the student passes an examination. These units are as follows:

I. The student must be able to sing and write the scales of the tonic chord, in the keys of e-flat and f-major, getting the pitch from the pitch-pipe. These keys are used because they are within the staff and are pitched where the children sing.

2. The student must be able to sing at sight each measure of an exercise or song in 4-4, 3-4, or 6-8 time, with one sound to a beat, one sound to two beats, one sound to three beats, one sound to four beats, two equal sounds to one beat, and, in the case of 6-8 time, one sound to five or six beats using the keys and intervals studied in $\mathrm{I}$.

3. The student must be able to recognize and sing at sight skips of thirds, fourths, and fifths in the same two keys, and to apply them in the songs of Book I, and also to pass a sight reading examination in an unknown song involving only these problems.

This is the outline of the course in music which must be mastered by any student before she is allowed to teach the simple primary songs. 
In the fall of 1920 a survey of the students in the San Francisco State Normal School produced the fact that there were twenty-four who were conspicuously unsuccessful in their study of the music course after having carried it for three months. These students were not able to sing the songs alone either at sight when presented on the written page, or in true intonation. In order to determine whether or not the difficulty was one of inability to hear the tone differences which they could not produce, they were given the four sensory discrimination tests and the tonal memory test which have been recorded on the phonograph by Seashore.

The Seashore tests do not need a detailed description here. Suffice it to say that there is a test for pitch discrimination, one for intensity discrimination, one for the discrimination of duration of time intervals, one for the discrimination of the relative consonance of musical tones, and, finally, a test for immediate memory span for a series of nonsense musical tones. ${ }^{1}$ These tests have been standardized and norms of percentile rank are published in the Manual.

To return to our students who are trying to learn to sing. The supervisor asks, "What is the cause of this inability to learn elementary music? Is it a general cause, or are there differences in their native capacity which make music so difficult for them to grasp; and how can I help each one most effectively?"

Before the tests were given, the twenty-four girls were sorted into three groups: (I) Six students of whom there was some hope that slowly and gradually they might come up to the required standard. These were called "hopeful." (2) Six students of whom the supervisor was in grave doubt, but of whom she still entertained a hope that by unusual diligence they might reach the standard. These were called "doubtful." (3) Twelve students who, the supervisor felt, gave unmistakable evidences of never being able to meet the required standard. These were called "hopeless." This ranking was done by the supervisor,

${ }^{1}$ Seashore, Psychology of Musical Talent, Silver, Burdett \& Co. See also Manual of Instructions and Interpretations for Measures of Musical Talent, Columbia Graphophone Co., New York. 
entirely independent of the psychologist, and purely upon her observation of the actual achievement of the students, but in the light of her teaching experience.

Table I shows the percentile ranks of the twenty-four students according to the Seashore tests. In percentile ranking the highest possible mark is 100 , the lowest is $\mathrm{I}$, and the median is 50. An average of percentile ranks does not have any particular significance, since the tests are of different values in diagnosis, but it is desirable to have some general designation of the individual record as a whole. For the purpose of grouping I have called the records which on the average fall between $I$ and $I 5$ in rank, very inferior; those from 16 to 30 inferior; those from 3 I to 47 fair; and those above 48 good. $^{2}$

TABLE I.-PERCENTILE RANKS ACCORDING TO THE

SEASHORE, TESTS

\begin{tabular}{|c|c|c|c|c|c|c|}
\hline & $\begin{array}{l}\text { STUDENT'S } \\
\text { NUMBER }\end{array}$ & Pitch & INTENSITY & Time & Consonance & Memory \\
\hline $\begin{array}{l}\text { 㞩 } \\
\text { 商 } \\
\text { 号 }\end{array}$ & $\begin{array}{l}1 \\
2 \\
3 \\
4 \\
5 \\
6 \\
\end{array}$ & $\begin{array}{l}36 \\
87 \\
56 \\
87 \\
63 \\
29 \\
\end{array}$ & $\begin{array}{l}82 \\
74 \\
45 \\
22 \\
25 \\
25 \\
\end{array}$ & $\begin{array}{l}83 \\
32 \\
24 \\
54 \\
20 \\
32 \\
\end{array}$ & $\begin{array}{r}68 \\
6 \\
86 \\
46 \\
56 \\
56 \\
\end{array}$ & $\begin{array}{l}16 \\
60 \\
37 \\
30 \\
\dot{13} \\
\end{array}$ \\
\hline 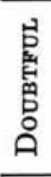 & $\begin{array}{r}7 \\
8 \\
9 \\
10 \\
11 \\
12 \\
\end{array}$ & $\begin{array}{r}10 \\
87 \\
29 \\
3 \\
1 \\
26 \\
\end{array}$ & $\begin{array}{r}58 \\
14 \\
19 \\
51 \\
4 \\
25 \\
\end{array}$ & $\begin{array}{r}61 \\
20 \\
73 \\
24 \\
2 \\
3\end{array}$ & $\begin{array}{r}56 \\
18 \\
1 \\
18 \\
78 \\
3\end{array}$ & $\begin{array}{r}30 \\
41 \\
5 \\
2 \\
3 \\
\ldots\end{array}$ \\
\hline $\begin{array}{l}\text { 吕 } \\
\text { 善 } \\
\text { 总 } \\
\text { 品 }\end{array}$ & $\begin{array}{l}13 \\
14 \\
15 \\
16 \\
17 \\
18 \\
19 \\
20 \\
21 \\
22 \\
23 \\
24\end{array}$ & $\begin{array}{r}1 \\
9 \\
29 \\
13 \\
5 \\
1 \\
26 \\
1 \\
4 \\
1 \\
1 \\
3\end{array}$ & $\begin{array}{r}66 \\
87 \\
58 \\
66 \\
51 \\
5 \\
4 \\
19 \\
22 \\
10 \\
19 \\
4\end{array}$ & $\begin{array}{r}78 \\
28 \\
37 \\
16 \\
24 \\
3 \\
24 \\
9 \\
32 \\
28 \\
13 \\
4\end{array}$ & \begin{tabular}{r}
56 \\
36 \\
18 \\
46 \\
26 \\
78 \\
3 \\
36 \\
1 \\
$\ldots$ \\
\hdashline \\
1
\end{tabular} & $\begin{array}{r}2 \\
34 \\
23 \\
12 \\
11 \\
3 \\
\because 3 \\
5 \\
3 \\
1 \\
1\end{array}$ \\
\hline
\end{tabular}

2 A Survey of Musical Talent in the Des Moines Public Schools, Child Welfare Research Station, Univ. of Iowa, 1920. 
When it is understood that the rating hopeful,-doubtful, and hopeless was independent of the sensory tests, and when the rank of the students in each category is studied, a distinct correlation is immediately perceived. This is more fully brought out in Table II. In this table the divisions good, fair, inferior, and very inferior are based upon the general results of the five

TABLE II.-RELATION BETWEEN SUPERVISORS' JUDGMENTS AND RATINGS ACCORDING TO THE SEASHORE TESTS

\begin{tabular}{|c|c|c|c|c|}
\hline \multirow[b]{2}{*}{$\begin{array}{l}\text { SUPERVISOR's } \\
\text { Classification }\end{array}$} & \multicolumn{4}{|c|}{ Classification According to SEashore Tests } \\
\hline & $\begin{array}{c}\text { Very } \\
\text { Inferior }\end{array}$ & Inferior & Fair & Good \\
\hline $\begin{array}{l}\text { Hopeful........ } \\
\text { Doubtful. } \ldots \ldots \ldots \ldots \ldots \ldots \ldots \ldots \\
\text { Hopeless. . } \ldots \ldots \ldots \ldots \ldots \ldots\end{array}$ & $\begin{array}{l}0 \\
1 \\
6\end{array}$ & $\begin{array}{l}0 \\
3 \\
3\end{array}$ & $\begin{array}{l}2 \\
2 \\
3\end{array}$ & $\begin{array}{l}4 \\
0 \\
0\end{array}$ \\
\hline
\end{tabular}

measurements of each individual. The divisions hopeful, doubtful, and hopeless are the empirical classifications of the supervisor. The figures in the spaces indicate the number of individuals under each of the double classifications. It is apparent that those who are hopeful are the highest in their sensory capacity, that those who are doubtful fall a little lower, and that those who are hopeless are undoubtedly the lowest in the sensory measurements.

I shall describe in detail a few of the cases. Each one is interesting and significant, but I shall limit my descriptions to a few of the more dramatic ones. I shall refer to them by the numbers used in Table I.

The supervisor's comment on No. 1 in September was that she had no experience and was very timid. It was this timidity that made me feel that the results of the first group tests were probably unreliable, and I tested her again with the results given in the table. Three months later the supervisor reported that while she was not especially strong in music and was very lacking in self-confidence, she was slowly learning the required songs and would be able to teach the simple songs at least. The student herself reports that when she learns the songs with the syllables she cannot then transfer the words to the melody and, therefore, is very slow in learning the material. The process demanded 
by the teachers (that of first learning the syllables) which is a help to many, is a hindrance to her. Her motor coordinations are persistently inflexible with this resultant difficulty. She also has a distinct sensory inferiority, since she does not remember tones, as such, as well as the majority of normal people do. These two weaknesses, in connection with a lack of self-confidence, will make her slow, but there is no reason why she cannot ultimately learn the music required.

No. 2 is a case of another timid soul who does not show her true capacity at first. In September the supervisor reported that she could not sing a melody alone. Three months later she reported that she was singing with great timidity and getting her work very slowly, but that she was able to sing the simple primary songs with an accurate voice of pleasing quality. It is not a sensory difficulty, then, as the tests show, nor a motor difficulty, as the accuracy of her singing shows, but a temperamental difficulty; and she is, therefore, properly classified as "hopeful."

No. 8 was found to be fair in her sensory capacity. The supervisor said: "Her voice flats; she cannot remain true." Three months later, although the student had been working faithfully at her music, the same report was made. In the supervisor's words: "Her voice flats very markedly; she goes quite off and it is a surprise to her that she isn't doing it correctly. She only approximates a tune. She can read and is trying hard to finish her music. If she could retain the pitch, she would be all right." No. 8 is one in whom the sensory capacity is not the important weakness; her difficulty is in motor capacity. There are people who can see a ball and who can hold a tennis racquet, but who have great difficulty in learning to hit the one with the other. In the same way there are those who hear the pitch of tones and who can use their voices for ordinary purposes, but who cannot hit the pitch of the tones accurately with their voices. No. 8 is an illustration of this kind of motor difficulty. She will have to take very intensive practice in gauging the pitch distances which her voice must control; and by such drill alone will she be able to improve the accuracy of her singing. 
No. Io was reported in September as having no musical experience. Three months later the supervisor said of her, "She appears to have no conception of what reading means. She doesn't look at the right place in the book. She can imitate tones but seems to have no power to concentrate on the problem of reading." With her inferior rank in the sensory tests she probably cannot remember the tones for any length of time. She may have no particular weakness in motor capacity, but if, in addition to her inability to learn to read the notes, she is further handicapped by inferiority in intelligence, she will probably never be able to do even the minimum in music.

No. 15 was reported as being weak in music, but the supervisor was not sure whether this was due to lack of previous experience or to natural incapacity. Three months later the supervisor had found that No. 5 could not yet sing a melody and had very little conception as to whether or not she was singing correctly. She displays fair sensory capacity but is probably lacking in motor control and coordination. She is very intelligent and could undoubtedly improve her motor attack to some extent.

No. I7 was simply reported as being weak in music. Later the supervisor noted that if she worked on a tune long enough, she got it but not with perfect accuracy. Another supervisor asked her in my presence to sing a tiny melody of four tones not more than a step apart. She made three attempts but went in the wrong direction on each trial. The tests show that she is distinctly inferior in her sensory capacity, and she is also evidently inferior in her motor capacity. Whatever she learns to sing will be acquired slowly and with great difficulty and will never be accurately retained. She loves, however, to listen to music and works diligently at it, although she knows that she is accomplishing very little.

No. 22 was reported as having no previous knowledge of music. Three months later the supervisor's report says, "She sings down when the notes go up, and vice versa. Time values she also cannot comprehend, although she has had special training in a small class. A song that she once learns, largely by 
hearing it, she can sing." Here is a case of very inferior sensory capacity linked with inferior intelligence which means that she will learn even the minimum amount of music only by the greatest expenditure of effort on her part and specially adapted training on the part of her teachers.

From these briefly described cases some general observations may be made. Difficulties in learning music are of at least two distinct kinds; there are sensory weaknesses and there are motor weaknesses. Each may exist in an individual by itself or in connection with the other. Either one alone puts the possessor into the class of those who learn music slowly, painstakingly, and -often in the end after much effort-ineffectively. If to these weaknesses is added slowness in general intelligence the situation becomes even more difficult. Those who are found to be of either or all of these three classes must be trained individually by methods specially adapted to the particular case.

At the San Francisco State Normal School an effort is being made to give special training to these students. The work is yet in the experimental stage, so that I cannot describe any final results. The students who were graded as hopeless have been grouped together into a special class, where they are taught to sing some simple primary songs together by note. These they sing with haziness of intonation but with a rather surprising approximation to the pitch. When each student sings alone, she is not at all sure of herself. The quality or timbre of their singing is very bad, and apparently they are very vague in a conscious conception of what they are doing. By this I mean that they are not accurate in the beginning and ending of phrases or in the actual relationship of pitches. They rely upon their teacher and upon one another. I felt when I heard them sing in a group and individually as I do about a little child who is learning to walk. I admire his tottering efforts when I consider that he is a little child. But if I consider his achievement as walking I must admit that it is not a very successful performance. So I feel about these students who are deficient on the sensory or motor sides of their inborn equipment for music; it is surprising 
that they can sing at all, propping themselves up on each other and leaning on their teacher, but as real singers they are very bad.

The results of this study, reinforced by previous observations of similar cases, lead me to the belief that those who are weak or inferior in hearing the characteristics of musical tones will be weak and slow in reproducing them. It would undoubtedly be more economical of effort, both on the part of the student and of the teacher, if they could be released from the drudgery of trying to learn something which is so difficult, and could turn their energy and talents to a field where achievement would be more notable. But, since under the present circumstances we must train them as well as we can, we must reinforce their auditorymotor weaknesses by artificial associations. For instance, the tonoscope may be used to give a visual correction of faulty intonation, or an artificial association of tones with colors may be deliberately used to improve tonal memory. Various synesthesias, according to the needs and capacities of each individual, may be worked out as crutches for the lame ducks in music. This immediate problem of forming artificial associations is a very interesting one on which I hope to be able to report later. 